\title{
Autologous Lymphoma Cell Lysate-Pulsed Autologous Dendritic Cell Vaccine
}

National Cancer Institute

\section{Source}

National Cancer Institute. Autologous Lymphoma Cell Lysate-Pulsed Autologous

Dendritic Cell Vaccine. NCI Thesaurus. Code C85452.

A cell-based cancer vaccine composed of autologous dendritic cells (DCs) pulsed with lysate from autologous lymphoma cells with potential immunostimulatory and antineoplastic activities. Upon intranodal administration, autolog ous lymphoma cell lysate-pulsed autologous DC vaccine may stimulate the immune system to mount antitumoral cytotoxic T lymphocyte (CTL) and antibody responses against lymphoma cells, which may result in lymphoma cell lysis. 